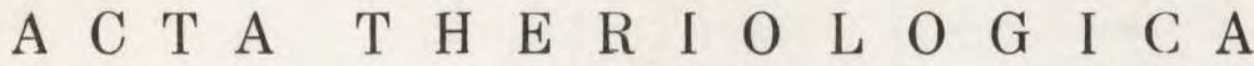

\section{Studies on the European Hare. VIII. Dynamics of Occurrence of Listrophorus gibbus Pagenstecher, 1862}

\author{
[With 11 Figs, \& 8 Tables]
}

A total of 350 dead hares was examined and 6928 mites were collected. Two methods were used in the investigations: the "combing" method and the method given the working term "bag" method. An attempt was made at assessing the effectiveness of the methods used. Examination was made of the problem of the mites' activity, expressed in the abandonment of the dead hare by L. gibbus. It was found that during the study period (11 months) the behaviour of the mites underwent qualitative changes. $L$. gibbus passes through the whole of its development cycle on hares. The age and sex structure of the population is not constant but is subject to fluctuations. From April to June and from December to February individuals termed juvenile predominate. From July to November changes were observed each month in the age structure of the minute populations examined. Extensiveness and intensiveness of infection are seasonal in character. The highest indices of extensiveness and intensiveness of invasion were recorded during period April-July, medium in August-November and lowest in December-February. Intensiveness of infection of young hares is markedly lower than in old hares. The mechanism regulating the numbers in populations of $L$. gibbus is connected with the age and sex structures of the ectoparasites.

I. Introduction

II. Methods

the 29

1. Combing the fur of dead hares . . . . . . . . . 29

a. The problem of the possibility of combing out all the mites in the hares' fur

b. Elaboration of a working method . . $\quad 34$

2. Bag method . . . . . . . . . . . . . . . . . 35

3. Combing the fur of live hares. . . . . . . . . 36

4. Summary of investigations of quantitative methods . . . . . . 36

III. Material . . . 36

IV. Process of abandonment of hares by mites after the host's death . . . $\quad 37$

V. Age and sex structures of a population of L. gibbus . . . . . . 40

1. Old hares...... . . 40

2. Young hares . . . . . . . . . . . . . . 43 
VI. Extensiveness of infestation . . . . . . . . . . . 45

VII. Intensiveness of infestation . . . . . . . . . . . . . 47

VIII. Discussion of results . . . . . . . . . . . . . . . . 48

References . . . . . . . . . . . . . 52

Streszczenie

\section{INTRODUCTION}

The object of investigations was formed by hares from the Poznan province obtained in numbers of 50 individuals a time from shoots carried out once a month over a period of one week. The hares shot in a given month were treated as one sample in the investigations. I was allotted the investigation of ectoparasites as my part in these studies.

Representatives of Anoplura, Aphaniptera (Spilopsyllus cuniculi) ${ }^{1}$ ), ticks (Ixodes ricinus) ${ }^{1}$ ), and Acarina of the genus Dermanyssus were found to occur on the hares examined. The parasites mentioned above occurred sporadically and in small numbers, whereas Listrophorus gibbus Pagen ste cher, 1862 (Acarina, Sarcoptiformes, Listrophoroidea) was relatively abundantly represented. The present study has been devoted to this species.

The aim of the study was to examine the age and sex structure of a population of L. gibbus, and the extensiveness and intensiveness of infestation of the hares from the seasonal aspect. In this connection it proved essential to determine whether the "combing-out" method and the method given by the working term "bag-method" were effective.

L. gibbus was described from Austria as a parasite of the wild rabbit by $\mathrm{P}$ a g e n$\mathrm{ste} \mathrm{ch}$ er in 1862. Mites beionging to the super-family Listrophoroidea live in the fur of mammals and have a mouth apparatus of the biting type. Pagenstecher (1862) states that $L$. gibbus feeds on the epidermis. Will man $\mathrm{n}$ (1952) is of the opinion that species belonging to the genus Listrophorus cannot be considered true parasites, since according to him they feed on the secretions of the skin. Z a va di 1 (1962) states - when L. gibbus occurs in sufficient numbers it can cause the host's fur to fall out, and encloses a photograph of a hare, showing this.

Information on the subject of $L$, gibbus is somewhat scanty. Of recent years it has been recorded as occurring on Oryctolagus cuniculus ( $\mathrm{L}$ in n a e u s, 1758) and on Lcpus europaeus in Czechoslovakia ( $\mathrm{Z}$ a p le t a 1, 1960). Z a v a dil (1962) also confirms that L. gibbus occurs on the hare. In the Soviet Union this species is known from the fur of rabbits (D ubinin, 1955), while $L$. gibbus has not as far been noted in Poland.

Very little study has been made of this species even from the systematics aspect. only the males are identifiable. On account of the investigation of the age structure of populations of $L$. gibbus occurring on the hares examined it was necessary to distinguish nymphs from females. This proved to be a relatively easy task, even in the case of mites placed sidewards in the preparation, that is, with a poor view of the genital apparatus. It is not, however, easy to distinguish nymphs I from nymphs II and for this reason when discussing age and sex structure these stages of development have been treated jointly, terming them simply nymphs. In passing it

1) I should like to take this opportunity of thanking Dr. S. Szymans $\mathrm{ki}$ for identifying the ticks and M. J a n i on M. Sc. for indentifying the fleas. 
must be emphasised that the figure (Fig. 2, tab. XVII) in Pagenstecher's study (P agenstecher, 1862) is erroneous, since it represents a nymph, and not as stated, a female. An identical error is contained in figure N. 128 in the study by D u b in in (1955).

\section{METHODS}

I found descriptions of different ways of catching ectoparasites in parasitological literature, without, however, any estimate of the effectiveness of the methods used (B e e r, C o ok \& S c hw a b, 1959; M o h r \& Lord, 1960; L a y ne, 1963 and others). The method consisting in combing out parasites is well known and commonly used, as is the method of collecting ectoparasites from bags, yet I found no data on their effectiveness and I have therefore attempted to assess it.

The hares shot in the Poznan province were sent to Warsaw, the interval hetween the time at which they were shot to the time of their delivery to the laboratory usually being from $1-5$ days. As is well known, parasites abandon a dead animal relatively rapidly, therefore in order to prevent the mites from escaping from the dead hare the latter was placed in cotton bag after it was shot. A label giving the date and the place where the animal was shot was attached to each bag. The mites which abandoned the dead hare congregated in the bag.

\section{Combing the Fur of Dead Hares}

Examination of the hares was made by using two methods: the combing method and the method given under the working name of bag method. After removing the hare from the bag the animal was combed over a white cardboard sheet spread beneath the body. The mites were combed out from the back, belly and sides of the body, but for technical reasons the head and legs were not combed. The mites combed out in this way were tipped from the cardboard to a Petrie dish, then examined under a stereoscopic microscope with $36 \times$ magnification. Permanent preparations of the mites collected were made in Faure-Berlese fluid. Metal combs were used, the base of which was $9 \mathrm{~cm}$ long, and height of teeth $2.5 \mathrm{~cm}$. The teeth of the comb were spaced at intervals at the base of $0.1 \mathrm{~cm}$. After each hare had been thoroughly combed the comb was singed over a spirit lamp to prevent mites being carried from one hare to another.

a. The problem of the possibility of combing out all the mites in the hares' fur

It was decided to check by means of two experiments, whether it is practically possible to comb out all the mites in the fur of a hare. One 
hare which proved to be densely infested by the parasites was used for experiment 1 , and a hare only slightly infested for experiment 2 .

Experiment 1 was carried out as foilows: four strokes of the comb formed one series of combings (once along the back, once along the belly and once on each side of the body). On account of the extreme laboriousness of the proceeding only the mites from odd series (series 1,3 ,

Table 1.

Variations in the effectiveness of combing out a densely infested hare.

\begin{tabular}{|c|c|c|c|c|c|c|}
\hline \multirow{2}{*}{$\begin{array}{l}\text { Sequences } \\
\text { of sertes }\end{array}$} & \multicolumn{2}{|l|}{ Series } & \multirow{2}{*}{$\begin{array}{l}\text { No. of } \\
\text { combings }\end{array}$} & \multirow{2}{*}{$\begin{array}{l}\text { Consecut1ve } \\
\text { number of } \\
\text { combings }\end{array}$} & \multirow{2}{*}{$\begin{array}{l}\text { No. of } \\
\text { mites }\end{array}$} & \multirow{2}{*}{$\begin{array}{l}\text { Mean number } \\
\text { of nites } \\
\text { per comb1ng }\end{array}$} \\
\hline & Numbers & $\mathrm{n}$ & & & & \\
\hline I & $1-17$ & 9 & 36 & $1-36$ & 131 & 3.64 \\
\hline II & $19-33$ & 8 & 32 & $37-68$ & 131 & 4.09 \\
\hline III & $35-57$ & 12 & 48 & $69-116$ & 146 & 3.04 \\
\hline IV & $59-67$ & 5 & 20 & $117-136$ & 18 & 0.90 \\
\hline $\begin{array}{l}\text { Interval in } \\
\text { comb1ng of } \\
\text { about } 10 \text { hours }\end{array}$ & & & & & 159 & \\
\hline $\mathrm{v}$ & $69-85$ & 9 & 36 & $137-172$ & 27 & 0.75 \\
\hline VI & $87-107$ & 11 & 44 & $173-216$ & 13 & 0.29 \\
\hline
\end{tabular}

Column 6 , line 5 - Number of mites which abandoned the hare during the interval (night) between sequence IV and V of combing.

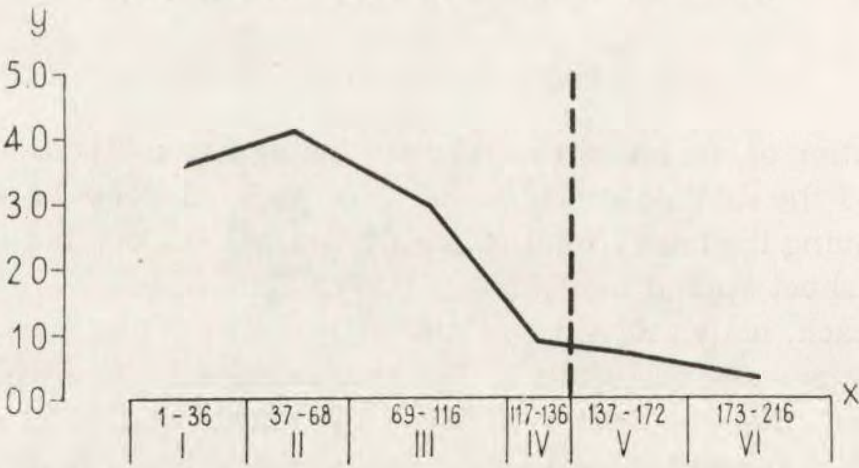

Fig. 1. Variations in effectiveness of combing (densely infested hare).

$\mathrm{Y}-$ number of mites per 1 combing in sequence, $\mathrm{X}-$ consecutive number of combings and sequence of series.

5 etc.) were examined (i.e. preparations of the mites, which were then made, counted and identified). After making a large number of series of combings, this process was interrupted (for a period of from 1.5 to 2.5 hours), the interval being used to make preparations, on completion of which combing was begun again. The consecutive groups of series of combings separated from each other by an interval of time, were termed a sequence of combings. 
Combing of the hare examined in experiment 1 lasted 2 days, with a break for the night, as shown in table 1 and marked in Fig. 1. The hare was fastened for the night to special tenterhooks, under which a cardboard sheet was placed. The mites which left the dead hare during the night were grouped more or less evenly round the body on the cardboard. The mites were then collected from half the total surface of this cardboard, preparations made and counted (Table 1). The number of strokes of the comb (combings) in each sequence of combings differed, and thus made it impossible to estimate the effectiveness of combing. It was therefore necessary to introduce some standard common to all the sequences. The mean number of mites cormbed out by one stroke of the comb $(y)$ was therefore taken as this standard. The results obtained, comparable in this way, are illustrated by Fig. 1.

It was found from calculations that the mean number of mites combed out with one stroke of the comb $(y)$ varies. A slight tendency to increase in the mean $(y)$ can be observed between sequences I and II, and between sequences II and III a slight tendency to decrease. A sharp decrease was observed between sequences III and IV. A tendency to decrease, although a very slow one, is maintained between sequences IV and V and between $V$ and VI. Sequence II is characteried by the highest value of the mean (y). The process of desertion of the dead hare by mites is indicated by a vertical line (Fig. 1) during the interval between combings (night). It is an interesting fact that the large number of mites (Table 1) which abandoned the hare through the night did not have any distinct effect on the mean value $(y)$ obtained from the next sequence of combings. The value of the mean of sequence VI is about 12 times smaller than the value of the mean (y) for sequence I.

The plan of experiment 2 was altered slightly in comparison with experiment 1 . The changes consisted in one series of combings equalling only 2 strokes oi the comb (once along the back and once along the belly), and not 4 strokes as used in experiment 1 . Similarly to experiment 1 , preparations were made of only part of the mites combed out. The remaining mites were not taken into consideration. A total of 15 series ( 30 strokes of the comb) were made, which formed sequence $A$. The mites from these sequences were examined in detail. Sequence $A$ was followed by sequence $B$, consisting of 50 series ( 100 strokes of the comb), but no further work was done on mites from these sequences. There were $4 \mathrm{~A}$ sequences and $3 B$ sequences. In all 420 combings were made. The effectiveness of combings of the slightly infested hare is illustrated by Fig. 2.

The general character of the effectiveness of combings is similar to the results of experiment 1 . The value of the mean $(y)$ varies. Between 
sequence I and II a tendency to increase was noticed. Between sequence II and III a slow, and between III and IV a greater tendency to decrease occurs. Sequence II of combings is characterised by the highest value of mean $(y)$. As can be seen even after 420 combings not all the mites were combed out from the fur. The value of the mean $(y)$ sequence IV $A$ of combings (Tab. 2) is only about three times smaller than the value of mean $(y)$ of sequence I $A$.

Table 2.

Variations in the effectiveness of combing out a slightly infested hare.

\begin{tabular}{|c|c|c|c|c|c|c|c|}
\hline \multirow{2}{*}{\multicolumn{2}{|c|}{$\begin{array}{l}\text { Sequences } \\
\text { of series }\end{array}$}} & \multicolumn{2}{|c|}{ Series } & \multirow{3}{*}{$\begin{array}{l}\text { No. of } \\
\text { combings }\end{array}$} & \multirow{3}{*}{$\begin{array}{l}\text { Consecutive } \\
\text { number of } \\
\text { combings }\end{array}$} & \multirow{3}{*}{$\begin{array}{l}\begin{array}{l}\text { No. of } \\
\text { m1tes }\end{array} \\
9\end{array}$} & \multirow{3}{*}{$\begin{array}{l}\text { Mean number } \\
\text { of mites } \\
\text { per combing } \\
0.30\end{array}$} \\
\hline & & \multirow{2}{*}{$\frac{\text { Numbers }}{1-15}$} & \multirow{2}{*}{$\frac{n}{15}$} & & & & \\
\hline I & A & & & & & & \\
\hline I & B & $16-65$ & 50 & 100 & $31-130$ & & \\
\hline II & A & $66-80$ & 15 & 30 & $131-160$ & 13 & 0.43 \\
\hline II & B & $81-130$ & 50 & 100 & $161-260$ & & \\
\hline III & A & $131-145$ & 15 & 30 & $261-290$ & 11 & 0.36 \\
\hline III & B & $146-1.95$ & 50 & 100 & $291-390$ & & \\
\hline IV & A & $196-210$ & 15 & 30 & $391-420$ & 3 & 0.10 \\
\hline
\end{tabular}

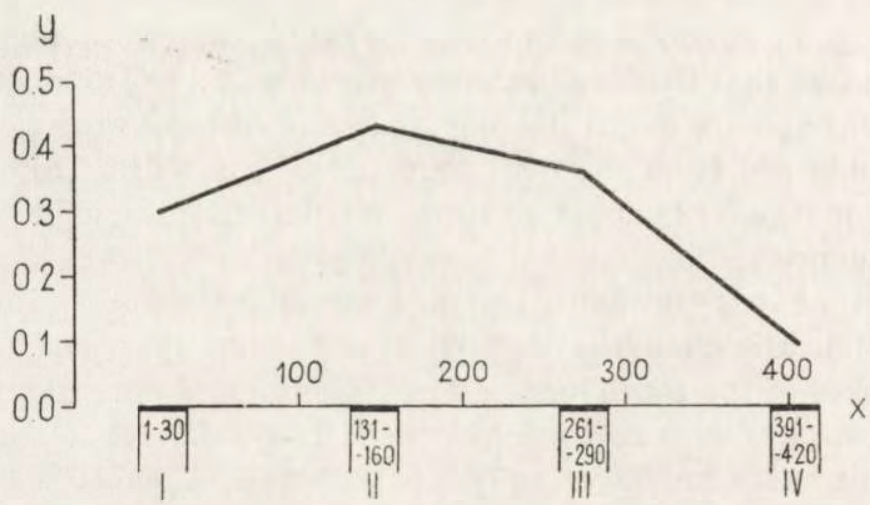

Fig. 2. Variations in effectiveness of combing (slightly infested hare).

In comparing the results of the experiments described we find differences and similarities in the effectiveness of combing. The basic difference observed between effectiveness of combing 2 hares with different degrees cf infestation by parasites is the rate at which the value of mean $(y)$ decreases. In experiment 1 the value of mean $(y)$ between sequence I and VI is about 12 times smaller, and in experiment 2 between sequence I $A$ and IV $A$ only about 3 times smaller. In neither experiment did it prove 
Table 3.

Variations in effectiveness of combing.

\begin{tabular}{|l|c|c|c|c|}
\hline Series & $\begin{array}{c}\text { No. cf } \\
\text { combings }\end{array}$ & $\begin{array}{l}\text { Consecutive } \\
\text { number of } \\
\text { combings }\end{array}$ & $\begin{array}{c}\text { No. of } \\
\text { mites }\end{array}$ & $\begin{array}{l}\text { Mean numbers } \\
\text { of mites } \\
\text { per combing }\end{array}$ \\
\hline I & 4 & 4 & 20 & 5.00 \\
II & 8 & 12 & 35 & 4.37 \\
III & 8 & 20 & 11 & 1.37 \\
IV & 8 & 28 & 27 & 3.37 \\
V & 8 & 36 & 31 & 3.38 \\
VI & 8 & 44 & 6 & 0.75 \\
VII & 8 & 52 & 12 & 1.50 \\
VIII & 8 & 60 & 14 & 1.75 \\
IX & 8 & 68 & 24 & 3.00 \\
X & 8 & 76 & 11 & 1.37 \\
XI & 8 & 84 & 9 & 1.12 \\
XII & 8 & 92 & 9 & 1.12 \\
XIII & 8 & 100 & 24 & 3.00 \\
XIV & 8 & 108 & 15 & 1.87 \\
XV & 8 & 116 & 5 & 0.62 \\
\hline
\end{tabular}

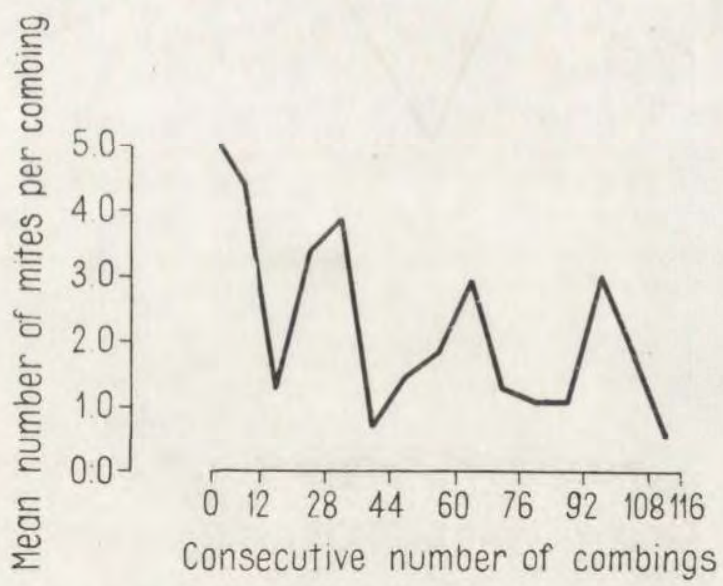

Fig. 3. Variations in effectiveness of combing.

possible to comb out all the mites in the hares' fur. In experiment 1 it might seem that the moment at which all the mites were combed out was very near. Mean $(y)$ from the final sequence of combings was about 12 times smaller than the mean (y) of sequence I, and was 0.29 . The results of experiment 2 in which the mean $(y)$ of sequence I $A$ of combings was 
similar to the value of the mean ( $y$ ) from the final sequence of experiment 1 and the fact that after 420 combings the value of this mean $(y)$ decreased by only 3 times must, however, lead to a different conclusion. It is practically impossible to comb out all the mites in a hare's fur and on this account it was both useful and necessary to search for a relative and not absolute method of quantitative investigation of parasite Acarofauna of hares.

Table 4.

Variation in effectiveness of combing.

\begin{tabular}{|c|c|c|c|c|c|}
\hline Series & I & 11 & I11 & IV & y \\
\hline $\begin{array}{l}\text { הo. of } \\
\text { combinss }\end{array}$ & 4 & 4 & 4 & 4 & 14 \\
\hline $\begin{array}{l}\text { Consecutive number } \\
\text { of combings }\end{array}$ & 4 & 8 & 12 & 16 & 20 \\
\hline $\begin{array}{l}\text { No: o: } \\
\text { nites }\end{array}$ & 65 & 30 & 56 & 50 & 42 \\
\hline $\begin{array}{l}\text { Mean number of } \\
\text { mites per combing }\end{array}$ & 15.50 & 7.50 & 14.00 & 12.50 & 10.50 \\
\hline
\end{tabular}

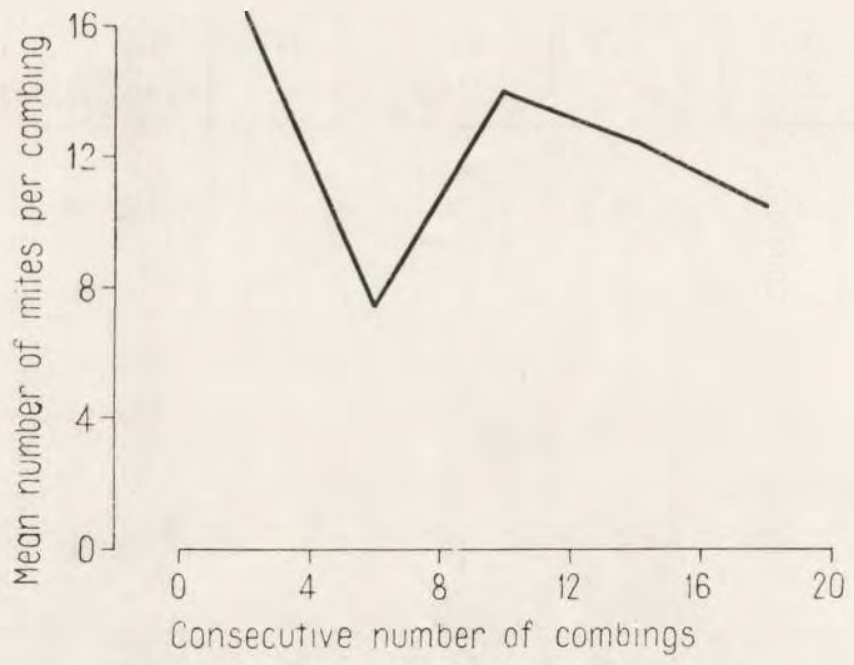

Fig. 4. Variation in effectiveness of combing.

b. Elaboration of a Working Method

The next experiments were aimed at determining the minimum number of combings, which, however, had to be sufficient to ensure that representative results were obtained. Experiments 3 and 4 were therefore made with this aim in view.

Five hares were used for experiment 3 . One series of combings consisted of 8 strokes of the comb: twice along the back, twice along the belly and 
twice along each of the sides of the body, (with the exception of the first scries which consisted of 4 single strokes of the comb). There were 15 of such series, that is, 116 combings (Table 3 ). The results obtained are illustrated by Fig. 3 .

As in the case of the previous experiments the value of the mean number of mites per 1 stroke of the comb $(y)$ was not a fixed one, but was subject to variation. The basic tendency of these variations is a decrease in the mean $(y)$ as combing proceeds.

Experiment 4 was carried out on 9 hares, the combing process being limited to 5 series. One series consisted of 4 strokes of the comb: once aiong the back, once aiong the belly and once on each of the sides of the body, giving a total of 20 strokes of the comb (Tab. 4). The results obtained are illustrated in Fig. 4.

The mean number of mites combed out with each stroke also varies. The vasic tendency of these variations is a reduction in the value of the mean $(y)$ as combing proceeds.

On the basis of results obtained from experiments 3 and 4 it was decided to accept 12 strokes of the comb as a standard for combing out each of the hares examined. These 12 strokes were taken as a minimum with which it was possible to obtain sufficiently representative results.

\section{Bag Method}

The mites which abandoned the dead hare congregated in the bag. After removing the hare from the bag, the latter was turned inside out and shaken on to a cardboard sheet placed beneath it. The parasites were then tipped on to a Petrie dish and the contents examined under a stereoscopic microscope, fixed preparations being made in exactly the same way as for the combings. Twenty-five shakes of the bag were taken as forming a standard number. All the bags which had contained hares were shaken in an identical way and elways by the same person. It must be emphasised that it did not prove possible to shake out all the mites in the bag on to the cardboard. Quite frequently single individuals adhering to the cloth remained in the bag.

It was found that only those hares which had remained in the bag for not longer than 2 days ( 48 hours) were suitable for examination. Hares which had been kept in bags for 3,4 or more days were unsuitable for quantitative examinations, the number of mites being markedly smaller and fortuitous. The number of hares examined after an interval of 48 hours was 21. A total of 55 mites was collected from the 11 adult males, and 10 mites from the 6 adult females, 2 mites from the 4 young females. 
Six of the males were infested, intensivity of infestation being 9.16. Intensiveness of infection of the 3 infested old females was 3.33 , and of the 4 young females only 2 were infested.

\section{Combing the Fur of Live Hares}

A total of 20 live hares were combed in February 1959. The aim of this experiment was to form an idea of the effects of combing live hares, although it was already known that these results could not be compared with the results of combings of dead hares. As a result of combing live hares a certain picture was obtained of the normal mite population undisturbed by the death of the host, which must affect in some way the manifestations of the life of a population of ectoparasites. On this account also it is difficult to compare the results of combings of live hares with the results of combing dead hares, or with the results obtained by means of the "bag" method.

In combing live hares 12 standard strokes of the comb were used, a total of 287 mites being obtained from 20 hares. Adult individuals were found to predominate (175 mites, i.e. $60.97 \%$ ). A total of 112 mites classified as belonging to the juvenile group were collected, i.e. $39.02 \%$. Extensiveness of infestation of the hares was $100 \%$, intensiveness 14.35 mites. The smallest number of mites found on one hare was 1 individual (in 2 cases) and the greatest 94 specimens (in one case).

\section{Summary of Investigations of Quantitative Methods}

Confrontation of the quantitative methods discussed for examining populations of acarinous ectoparasites revealed a lack of correlation between the "combing" method and the "bag" method. It must be considered that each of these methods in fact records only part of the manifestations of the life of mite populations. It must therefore be anticipated that summarising of the results of two methods burdened by error of selectiveness makes a certain reduction of this error possible, that is, makes it possible to obtain more objectively treated results. On this account material collected by means of the two methods was combined and treated jointly when considering of results. Figures representing the effectiveness of the methods used are given in Fig. 5.

\section{MATERIAL}

Approximately 50 hares were supplied each month for examination. For ectoparasitological purposes, on account of the great amount of labour involved, hares which were examined over 48 hours after being shot, or for which the date of shooting had not been recordea, or ior which it was impossible to determine the age (pelvis shot 
through and simultaneously head shattered), were rejected, a final total of 350 hares being accepted for examination. In the outcome the smallest number of hares was taken in August (24), and the greatest in October (40). Of the 350 hares, 195 males were examined (young hares 46 , old hares 149) and 155 females (young 40, old 115) (Table 5). Age classification was based on the identification made by $\mathrm{Ca}$ b o n $-\mathrm{R}$ a$\mathrm{czy}$ ńsk a (1964) and $\mathrm{Buja} \mathrm{Iska} \mathrm{(1964).} \mathrm{In} \mathrm{view} \mathrm{of} \mathrm{the} \mathrm{small} \mathrm{amount} \mathrm{of} \mathrm{material}$ analysis was made of 2 age groups only: old hares (classes $I I I+I V$ ) and young hares (classes $I+I I$, of authoresses mentioned).

Table 5 .

Number of hares examined (B) and infested (Z), divided according to sex and age class.

\begin{tabular}{|c|c|c|c|c|c|c|c|c|c|c|c|c|c|c|}
\hline \multirow{3}{*}{ Mont: } & \multicolumn{6}{|c|}{ Nales } & \multicolumn{6}{|c|}{ Fenales } & \multicolumn{2}{|c|}{ Total } \\
\hline & \multicolumn{2}{|c|}{ O1d } & \multicolumn{2}{|c|}{ Coung } & \multicolumn{2}{|c|}{ Tote1 } & \multicolumn{2}{|c|}{ old } & \multicolumn{2}{|c|}{ Young } & \multicolumn{2}{|c|}{ Tota 1 } & \multicolumn{2}{|c|}{ कृ 68} \\
\hline & B & 2 & 3 & 2 & 3 & 2 & 3 & $z$ & 3 & $z$ & 3 & $z$ & $B$ & 2 \\
\hline IV & 19 & 16 & 1 & 1 & 20 & 17 & 11 & 9 & 0 & 0 & 11 & 9 & 34 & 26 \\
\hline v & 21 & 18 & 0 & 0 & 21 & 18 & 11 & 7 & 1 & 1 & 12 & 8 & 33 & 26 \\
\hline VI & 19 & 18 & 4 & 4 & 23 & 22 & 8 & 7 & 2 & 1 & 10 & 8 & 33 & 30 \\
\hline VII & 10 & 5 & 7 & 4 & 17 & 9 & 9 & 4 & 4 & 2 & 13 & 6 & 30 & 15 \\
\hline VIII & 5 & 4 & 6 & 3 & 11 & 7 & 7 & 6 & 6. & 4 & 13 & 10 & 24 & 17 \\
\hline IX & 7 & 5 & 9 & 8 & 16 & 13 & 11 & 5 & 4 & 3 & 15 & 8 & 13 & 21 \\
\hline $\mathrm{x}$ & 12 & 10 & 7 & 2 & 19 & 12 & 14 & 11 & 7 & 3 & 21 & 14 & 40 & 26 \\
\hline$x I$ & 18 & 8 & 3 & 1 & 21 & 9 & 12 & 3 & 6 & 2 & 18 & 5 & 39 & 14 \\
\hline XII & 11 & 3 & 5 & 1 & 16 & 4 & 12 & 6 & 5 & 1 & 17 & 7 & 33 & 11 \\
\hline I & 13 & 6 & 2 & 0 & 15 & 6 & 8 & 4 & 2 & 1 & 10 & 5 & 25 & 11 \\
\hline 11 & 14 & 6 & 2 & 0 & 16 & 6 & 12 & 3 & 3 & 1 & 15 & 4 & 31 & 10 \\
\hline Total & 149 & 99 & 46 & 24 & 195 & 123 & 115 & 65 & 40 & 19 & 155 & 84 & 350 & 207 \\
\hline
\end{tabular}

A total of 6,982 mites were collected, 4,751 of which were taken from males ( 509 from young hares, 4,242 from old ones), and 2,231 from females (101 from young females, 2,130 from old ones) (Table 6).

\section{PROCESS OF ABANDONMENT OF THE HARES BY MITES AFTER THE HOST'S DEATH}

When estimating the efiectiveness of the "bag" and "combing" methods, an interesting phenomenon connected with the process of desertion of the dead hare by mites was encountered. Over a certain period of time a predominating number of the mites (in relation to those combed out) left the hare during the first day after the animal had been shot. During the next 24 hours the remainder of the mites left the body. The total for these 48 hours gave the maximum number of mites. There was, however, a period in which the maximum number of mites were collected from the bags (in relation to the mites combed out) in which the hares had been kept for only 24 hours. After the expiry of the next 24 hour period the 
number of mites did not increase in relation to those combed out, in fact on the contrary, it decreased. As this kind of desertion of the dead hare by the mites lasted without change over a period of several months it must be assumed that this is not an accidental phenomenon and that it has some connection with the processes taking place in the life of the population of ectoparasites examined. This phenomenon is the more interesting in that it is not directly dependent on the external conditions connected with the seasons of the year. A change in the activity of the mites is not a direct reply to external habitat stimuli such as, for instance a rise in temperature in moisture or similar factors. This phenomenon is illustrated by Fig. 5 .

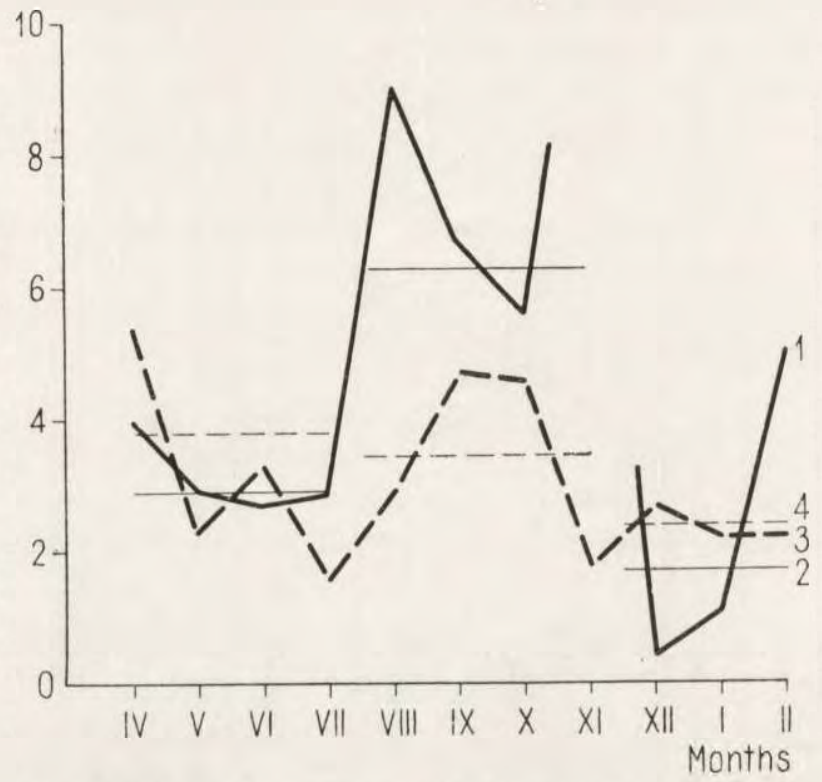

Fig. 5. Index of mites activity after the hare's death.

1 - Mean for month (1 day), 2 - Mean for period (1 day), 3 - Mean for month ( 2 days), $4-$ Mean for period ( 2 days).

Variations in the activity of mites were examined by means of the index of activity. This index was calculated separately for mites collected during the first day after the hare had been shot, and for mites collected from hares which had lain for in bags for 48 hours. The index of activity was obtained by dividing the number of mites collected from the bag in a given month by the number of mites combed out from the same hares. The index referred to expresses in figures the proportions between that part of the mite population which had abandoned the hare (collected from the bag) and the part which had been combed out from the fur. This ratio expressed numerically indicates that the mite population as a whole is more or less active in a given definite month in comparison with other periods. 
On the basis of the value of the index obtained it is possible to distinguish three periods in the life of the mites (during the period covered by the investigations under discussion)

Period $A$ covers: April, May, June and July,

Period B covers: August, September, October and November,

Period $C$ lasts through: December, January and February (Fig. 5).

During period $A$ the value of the activity index exhibits a distinct tendency to drop. The value of the index in period $B$ rises, then falls. A relatively high value of the index during this period is maintained for 3 months for hares examined during the period of 24 hours from the moment at which they were shot, and through 2 months for hares examined before the expiry of 48 hours from their death. In November (for hares examined before the expiry of 24 hours) the activity index of the mites was not calculated on account of the number of parasites being too small. In period $C$ the value of the index (for hares examined before the expiry of 24 hours) again begins to rise gradually, and for hares examined before the expiry of 48 hours this rise took place at once, and was maintained on this level until the end of the examinations.

Tendencies to variations in activity become even more distinct if each of the periods distinguished is treated as one sample and we calculate one index, maintaining at the same time division into the first day and two days after the shooting of the animals. The maximum value of the activity index calculated in this way characterised period $B$, the mean value period $A$ and the minimum value period $C$. The activity of the mites is of a different character in period $B$ in comparison with periods $A$ and $C$. The number of mites leaving the hares before the expiry of one day from the hares' death is distinctly greater (in relation to combed-out mites) than the number of mites which left the hares examined during the 48 hour period. It may be assumed that such results were obtained as the result of the mites escaping from the cotton bag, or that a greater degree of adhesion to the hare's fur or bag plays a part here. In any case it is a fact that during period $B$ the number of mites leaving the dead hares during the first day (in relation to those combed out) is greater than the number of mites which left the hares over the 48 hour period. The qualitative difference in the activity of mites in period $B$ (August-November) in comparison with periods $A$ (April-July) and $C$ (December-January) lies in the above fact. It is difficult at the present time to say what the causes of this phenomenon are and what biological sense it possesses. On the basis of the data given it may be stated that period $B$ differs qualitatively from periods $A$ and $C$. Period $C$ should be considered as the initial stage of per$\operatorname{iod} A$. 


\section{AGE AND SEX STRUCTURES OF A POPULATION OF L. GIBBUS MITES}

\section{Old Hares}

The age and sex structures were considered separately for mites collected from young hares and for old hares. The following categories were distinguished among the mites: larvae, nymphs, sexually mature males and females. In the group of females a further distinction was made between individuals which were observed to contain eggs and individuals in which eggs were not found. In the case of certain examinations larvae and nymphs were combined in a group of juvenile individuals, as opposed to the group of sexually mature individuals. Since hare shoots were organ-

Table 6 .

Number of mites collected from infested hares, split into the respective categories of hares.

\begin{tabular}{|c|c|c|c|c|c|c|c|}
\hline \multirow{2}{*}{ Month } & \multicolumn{3}{|c|}{ Males } & \multicolumn{3}{|c|}{ Females } & \multirow{2}{*}{ Total } \\
\hline & old & Young & Total & old & Young & Total & \\
\hline IV & 817 & 191 & 1008 & 778 & 0 & 778 & 1786 \\
\hline v & 1586 & 0 & 1586 & 394 & 10 & 404 & 1990 \\
\hline vI & 965 & 89 & 1054 & 106 & 1 & 107 & 1161 \\
\hline vII & 122 & 22 & 144 & 10 & 5 & 15 & 159 \\
\hline VIII & 36 & 27 & 63 & 259 & 32 & 291 & 354 \\
\hline IX & 153 & 149 & 302 & 156 & 26 & 182 & 484 \\
\hline $\mathrm{x}$ & 181 & 28 & 209 & 229 & 10 & 239 & 448 \\
\hline$X I$ & 157 & 2 & 159 & 7 & 7 & 14 & 173 \\
\hline XII & 118 & 1 & 119 & 27 & 3 & 30 & 149 \\
\hline I & 34 & 0 & 34 & 98 & 2 & 100 & 134 \\
\hline II & 73 & 0 & 73 & 66 & 5 & 71 & 144 \\
\hline Total & 4242 & 509 & 4751 & 2130 & 101 & 2231 & 6982 \\
\hline
\end{tabular}

ised once per month (over the period of one week), hence the analysis of the age structure of the mite populations was also made once a month. All the mites collected from hares in a given month were treated as one sample. The number of mites collected in a given month was taken as $100 \%$. In each such sample the percentage of stages distinguished was determined. The character of the age structure is illustrated by Fig. 6 and Table 7.

During the study period the occurrence of all the stages distinguished in the development of the mites was established, except that of eggs. The fact that no laid eggs were found must be attributed to the specific nature 
Table 7.

Age and sex structures of mite populations on old hares.

\begin{tabular}{|c|c|c|c|c|c|c|c|c|c|c|}
\hline & & 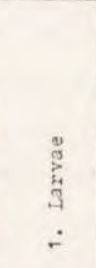 & 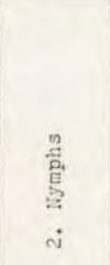 & 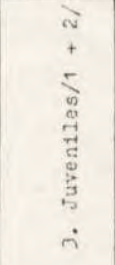 & 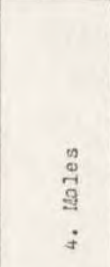 & 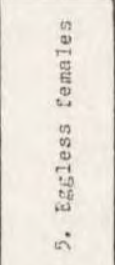 & 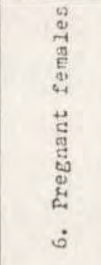 & 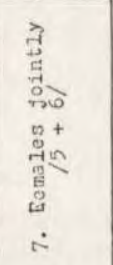 & 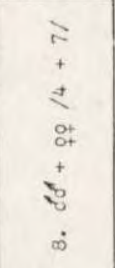 & 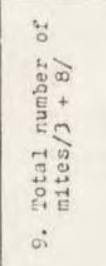 \\
\hline \multirow[b]{2}{*}{ IV } & $\mathrm{n}$ & 165 & 650 & $8: 5$ & 456 & 285 & 39 & 324 & 780 & 1595 \\
\hline & क & 10.34 & 40.75 & 51.09 & 28.59 & 17.37 & 2.45 & 20.32 & 48.91 & 100.00 \\
\hline \multirow{2}{*}{ V } & $n$ & 159 & 1005 & 1164 & ¿ 82. & $J 33$ & 151 & 534. & 816 & 1980 \\
\hline & $\Leftrightarrow$ & 8.03 & 50.76 & 59.79 & 14.24 & 19.34 & 7.63 & 25.97 & 41.21 & 100 \\
\hline \multirow{2}{*}{ VI } & $\mathrm{n}$ & 108 & 577 & 685 & 188 & 158 & 40 & 198 & 386 & 1071 \\
\hline & कs & 10.07 & 53.87 & 63.94 & 17.55 & 14.75 & 3.76 & 18.51 & 36.06 & 100 \\
\hline \multirow{2}{*}{ VII } & $n$ & 4 & 37 & 41 & 52 & 29 & 10 & 39 & 91 & 132 \\
\hline & $\%$ & 3.03 & 28.03 & 31.06 & 39.39 & 21.95 & 7.60 & 29.55 & 68.94 & 100 \\
\hline \multirow{2}{*}{ VIII } & $n$ & 29 & 157 & 186 & 34 & 46 & 29 & 75 & 109 & 295 \\
\hline & F & 9.83 & 53.22 & 63.05 & 11.52 & 15.60 & 9.83 & 25.43 & 36.95 & 100.00 \\
\hline \multirow{2}{*}{ IX } & $\mathrm{n}$ & 14 & 115 & 129 & 89 & 65 & 26 & 91 & 180 & 309 \\
\hline & $\%$ & 4.53 & 37.21 & 41.74 & 28.80 & 21.04 & 8.42 & 29.46 & 58.26 & 100.00 \\
\hline \multirow{2}{*}{$x$} & $n$ & 39 & 211 & 250 & 72 & 69 & 19 & $8 B$ & 160 & 410 \\
\hline & ह & 9.51 & 51.46 & 60.97 & 17.56 & 16.83 & 4.64 & 21.47 & 39.03 & 100.00 \\
\hline \multirow{2}{*}{ XI } & $\mathrm{n}$ & 5 & 68 & 73 & 40 & 44 & 7 & 51 & 91 & 164 \\
\hline & 2 & 3.05 & 41.46 & 44.91 & 24.39 & 26.83 & 4.27 & 31.10 & 55.49 & 100.00 \\
\hline \multirow{2}{*}{ XII } & $n$ & 21 & 62 & 83 & 29 & 28 & 5 & 33 & 62 & 145 \\
\hline & $x$ & 14.48 & 42.76 & 57.24 & 20.00 & 19.31 & 3.45 & 22.76 & 42.76 & 100.00 \\
\hline \multirow{2}{*}{ I } & $n$ & 17 & 69 & 86 & 19 & 25 & 2 & 27 & 46 & 132 \\
\hline & $\pi$ & 12.88 & 52.24 & 65.12 & 14.45 & 18.54 & 1.49 & 20.43 & 34.88 & 100.00 \\
\hline \multirow{2}{*}{ II } & $\mathrm{n}$ & & 71 & 81 & 23 & 32 & 3 & 35 & 58 & 139 \\
\hline & $\%$ & 7.19 & 51.08 & 58.27 & 16.55 & 23.01 & 2.17 & 25.18 & 41.73 & 100.00 \\
\hline \multirow{2}{*}{ Total } & $\mathrm{n}$ & 571 & 3022 & 3593 & 1284 & 1164 & 331 & 1495 & 2779 & 6372 \\
\hline & $\%$ & 8.96 & 47.42 & 56.38 & $=0.15$ & 18.25 & 5.21 & 23.47 & 43.62 & 100.00 \\
\hline
\end{tabular}

of the methods used. This most probably gives sufficient grounds for finding that $L$. gibbus passes through the whole cycle of its development on hares.

Proportions between each of the development stages distinguished are not constant, but are subject to greater or lesser fluctuations, Larvae and pregnant females (i.e. those in which eggs were found) are characterised by the low percentage of their participation in the mite population studied. 
Considerable fluctuations may take place within the limits of this percentage. The lowest percentage of pregnant females was found in April, January and February $(2.45 ; 1.49 ; 2.17 \%)$. Over a period of 3 months (July, August, September) a constant, relatively high percentage of pregnant females was observed $(7.60 ; 9.83 ; 8.42 \%)$. Nymphs and males are characterised by the highest percentage in the mite population, and fluctuations in their participation involved a change in the age structure of the ectoparasite population (Tab. 7).

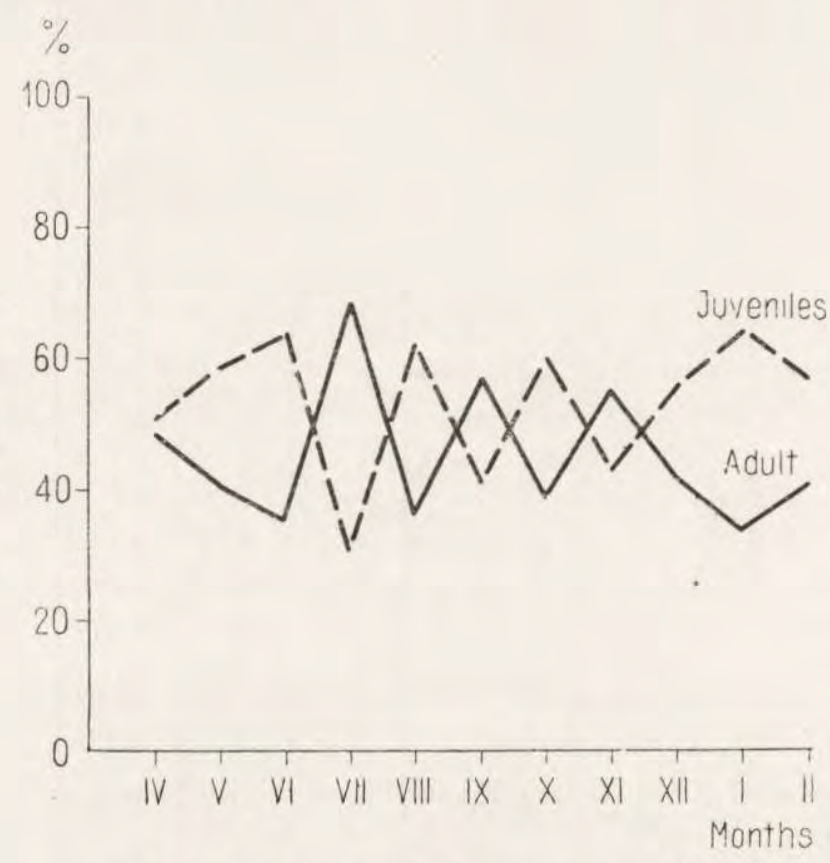

Fig. 6. Age structure of mites (adult hares).

Changes in the participation of the two groups of the L. gibbus population were also traced: the juvenile group (larvae and nymphs) and the group of sexually adult individuals (males and females). Fig. 6 illustrates the course taken by this process.

From April (the beginning of the studies) to June and from December to February (end of studies) individuals allocated to that part of the population termed juvenile predominated. The amplitude of fluctuations is very small and always in a definite direction. From July to November sudden, monthly variations were observed in the relations between the group of juvenile individuals and the group of sexually mature mites. Extreme fluctuations were observed in July. Fluctuations in the follow- 
ing months, in principle, exhibit a tendency to decrease. Considerable fluctuations with so great a percentage of these groups of mites is probably evidence of the rapid and intensive course of the life cycle. It is presumably connected with the shortening of the development period of nymphs and of the life-span of males, since these two categories determine the character of the fluctuations. The period of development of the eggs and larvae is probably very short, and the participation of larvae in the mite population during the study period was always small.

On the basis of the course taken by variations between the juvenile and mature parts of the population it is possible to distinguish 3 periods in the life of the mite population. These periods are: $A$ - from April to June, $B$ - from July to November, $C$ - from December to February, and they are to a great extent coincident in time with the character of the activity of the mites after the hare's death (Fig. 5).

It is an interesting fact that fluctuations in the age structure during period $A$ (April-June) are similar to the age structure during period $C$ (December-February) and not to period B (July-November). The above fact suggest that abiotic factors do not directly affect the manifestations of the life of the L. gibbus population. It is not impossible that the sudden fluctuations in the age structure in period $B$, or the absence of such fluctuations in periods $A$ and $C$ depend on some other, possibly biocenotic, factors.

\section{Young Hares}

All the development stages distinguished (with the exception of eggs) were found in mites on young hares, as they were in the case of old hares.

On account of the relatively small number of hares examined and the negligible degree to which they were infested (Tab. 5 and 8 ) the interpretation of results is difficult. The frequency of different stages of development differed. Larvae were noted in April and from June to November, while they were not found in the remaining months. Nymphs were represented in all the months examined. Eggless females not discovered in December and January only, and males in December and February. Pregnant females were found in the following months: April, May, June, July, August and September. No pregnant females were found from November to February.

If we count the months in which the occurrence of the given stage of development was noted, we find that not all the stages of development are recorded throughout the whole study period. Pregnant females were found only over a period of 6 months, larvae over 7 , and eggless females and males over 9. Only nymphs were found throughout the whole study period, that is, over 11 months. 
Table 8.

Age and sex structures of mite populations on young hares.

\begin{tabular}{|c|c|c|c|c|c|c|c|c|c|c|}
\hline & & 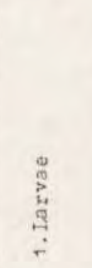 & 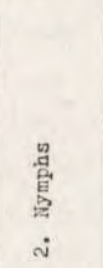 & 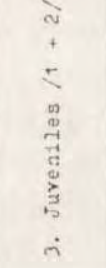 & $\begin{array}{l}0 \\
\text { o } \\
\text { a } \\
3 \\
\text { i }\end{array}$ & 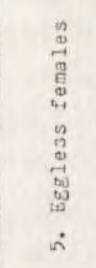 & 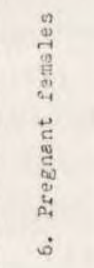 & 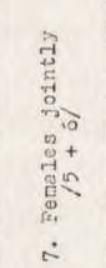 & 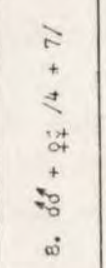 & 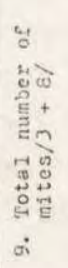 \\
\hline \multirow{2}{*}{ IV } & $\mathrm{n}$ & 17 & 105 & 122 & 24 & 35 & 10 & 45 & 69 & 191 \\
\hline & $\varsigma$ & 8.90 & 54.97 & 6). 87 & 12.57 & 18.32 & 5.24 & 23.56 & 36.13 & \\
\hline \multirow{2}{*}{ v } & $\mathrm{n}$ & 0 & 4 & 4 & 1 & 4 & 1 & 5 & 6 & 10 \\
\hline & $\%$ & 0.0 & 40.00 & 40.00 & 10.00 & 40.00 & 10.00 & 50.00 & 60.00 & \\
\hline \multirow{2}{*}{ VI } & $n$ & 8 & 31 & 39 & 14 & 24 & 13 & 37 & 51 & 90 \\
\hline & $\approx$ & 8.89 & 34.34 & 43.23 & 15.56 & 26.67 & 14.54 & 41.21 & 56.77 & \\
\hline \multirow{2}{*}{ VII } & $\mathrm{n}$ & 10 & 8 & 18 & 4 & 4 & 1 & 5 & 9 & 27 \\
\hline & $\infty$ & 37.03 & 29.64 & 66.67 & 14.82 & 14.82 & 3.69 & 18.51 & 33.33 & \\
\hline \multirow{2}{*}{ VIII } & $\mathrm{n}$ & 9 & 25 & 34 & 13 & 6 & 6 & 12 & 25 & 59 \\
\hline & 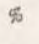 & 1524 & 42.38 & 57.62 & 22.02 & 10.18 & 10.18 & 20.36 & 42.38 & \\
\hline \multirow{2}{*}{$1 x$} & $\mathrm{n}$ & 23 & 72 & 95 & 35 & 24 & 21 & 45 & 80 & 175 \\
\hline & $\approx$ & 13.14 & 41.14 & 54.28 & 20.00 & 13.71 & 12.01 & 25.72 & 45.72 & \\
\hline \multirow{2}{*}{$x$} & $n$ & 9 & 13 & 22 & 4 & 12 & 0 & 12 & 16 & 38 \\
\hline & $\pi$ & 23.63 & 34.20 & 57.83 & 10.53 & 31.29 & & 31.59 & 43.12 & \\
\hline \multirow{2}{*}{ XI } & $n$ & 1 & 3 & 4 & 3 & 2 & & 2 & 5 & 9 \\
\hline & $\approx$ & 11.11 & 33.33 & 44.44 & 33.33 & 22.23 & 0.0 & 22.23 & 55.55 & \\
\hline \multirow{2}{*}{$K I I$} & $n$ & 0 & 4 & 4 & 0 & 0 & a & 0 & 0 & 4 \\
\hline & $\%$ & 0.0 & 100.0 & 100.0 & 0.0 & 0.0 & 0.0 & $0 . c$ & 0.0 & \\
\hline \multirow{2}{*}{ I } & $n$ & 0 & 1 & 1 & 1 & 0 & 0 & 0 & 1 & 2 \\
\hline & 5 & 0.0 & 50.0 & 50.0 & 50.0 & 0.0 & c. 0 & 0.0 & 50.0 & \\
\hline \multirow{2}{*}{ II } & $\mathrm{n}$ & 0 & 4 & 4 & 0 & 1 & 0 & 1 & 1 & 5 \\
\hline & s & 0.0 & 80.0 & 80.0 & 0.0 & 20.0 & 0.0 & 20.0 & 20.0 & \\
\hline \multirow{2}{*}{ Total } & $\mathrm{n}$ & 77 & 270 & 347 & 99 & 112 & 52 & 164 & 263 & 610 \\
\hline & 4 & 12.62 & 44.26 & 56.88 & 16.23 & 18.36 & 8.53 & 26.39 & 43.12 & \\
\hline
\end{tabular}

It is difficult to speak of the percentage of each stage of development in the mite population, if the percentage of their participation was calculated from a small total number of mites collected (e.g. 10 mites in May, 27 in July, or 9 in November). Nevertheless it would seem that these data may point to the existence of certain processes taking place in the life of a mite population. Bearing the foregoing premises in mind it is possible to find certain interesting regularities. In the months in which the pres- 
ence of pregnant females was recorded, their participation in the mite population on young hares was higher than in the mite population on old hares (Tab. 7, 8). The same may be said of larvae. The participation of nymphs was slightly higher in the mite population on old hares (participation of nymphs in young hares $-44.26 \%$, and in old hares $-47.42 \%$ ).

The role of nymphs in mite populations connected with young hares is exceptionally important. Their percentage is the highest of all the development stages distinguished, and their presence was noted over the whole of the study period. The assumption would appear justified that it

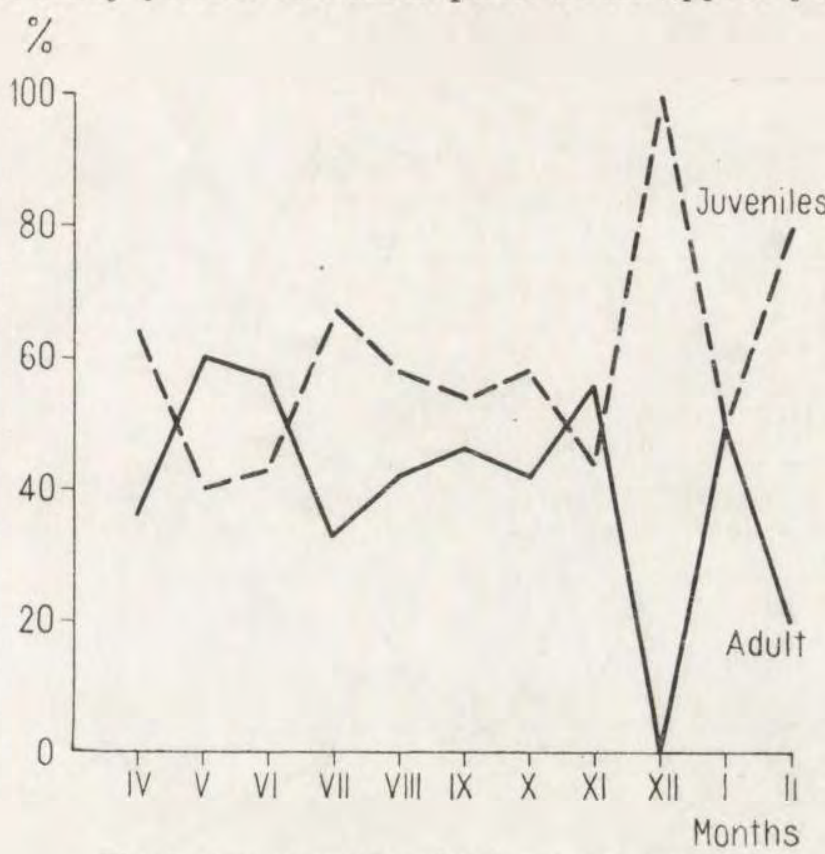

Fig. 7. Age structure of mites (young hares).

is this stage which is responsible for the infestation of hares hitherto free from mites. The nymphs have the opportunity, after transition to the class of mature individuals, to start within a short time a new mite population with a full spectrum of age and sex structure.

\section{EXTENSIVENESS OF INFESTATION}

The course taken by extensiveness of infection of old hares (divided into sex and age of the host) is shown in Fig. 8. The index mentioned was obtained by dividing the number of hares on which the parasites were found by the number of all the hares examined. If all the hares examined had been infested, then the index would equal 1. During the study period no such situation was found in the case of old hares, but 
considerable fluctuations in the value of this index were found, within limits from 0.95 (June) to 0.27 (December) for old males and from 0.88 (June) to 0.23 (February) for old females. The index of extensiveness of infestation calculated for the whole study period points to the fact that males are slightly more frequently infested (index 0.65 ) than females (index 0.55). Fluctuations in the index of extensivenes of infestation point to the existence of three periods $(A, B, C)$ of different extensiveness of infestation of the hare population. The highest values of the index of extensiveness were connected with period $A$, medium values with period $B$ and lowest with period $C$ (Fig. 8).

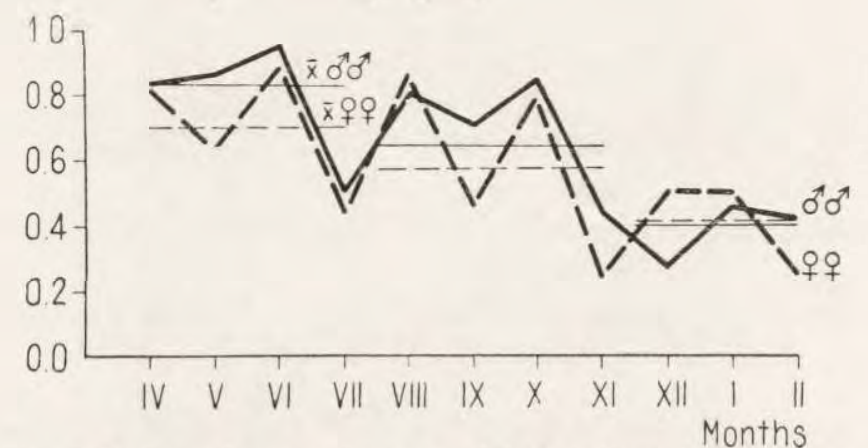

Fig. 8. Index of extensiveness of infestation of adult hares.

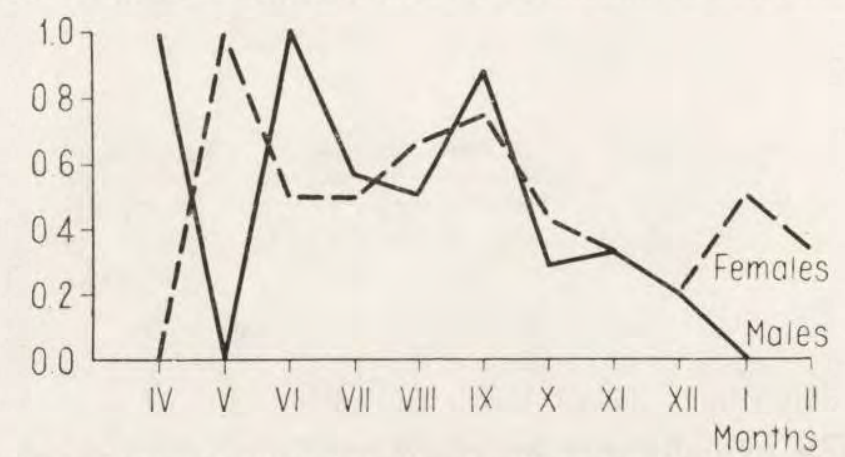

Fig. 9. Index of extensiveness of infestation of young hares.

As can be seen the majority of the hares are infested by mites in the spring after living through the winter. In November and the following months the majority of the hares were free from mites (Fig. 8). This tendency to decrease is more distinctly manifested when comparing means for periods.

The character of the extensiveness of infestation of young hares is illustrated by Fig. 9. It is, however, difficult to analyse the character of the infection in this part of the hare population on account of the small amount of material available as evidence. 
VII. INTENSIVENESS OF INFESTATION

The index of intensiveness of infection is expressed by the mean value from the collected number of mites on one infested hare (calculated for monthly or periodical samples). The character of intensiveness of infestation of old hares is illustrated by Fig. 10. Like the index of extensiveness of infection, the intensiveness index was calculated separately for young and old hares (split further into males and females). Three periods were

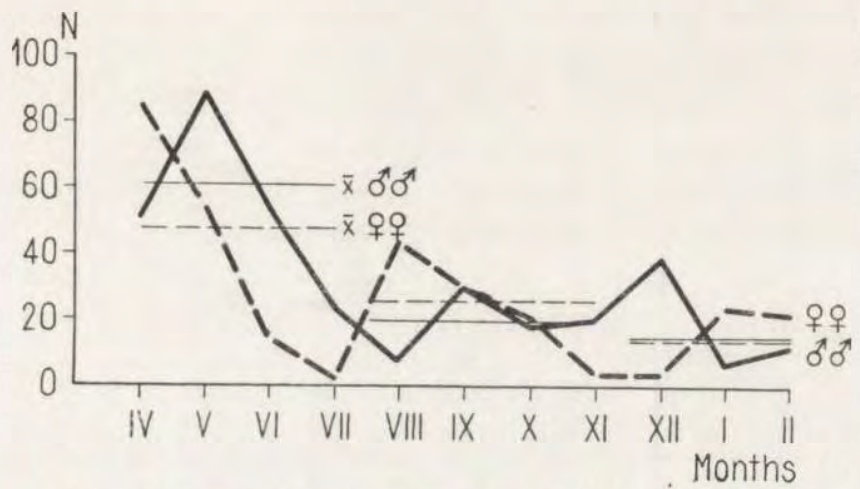

Fig. 10. Intensiveness of infestation of adult hares.

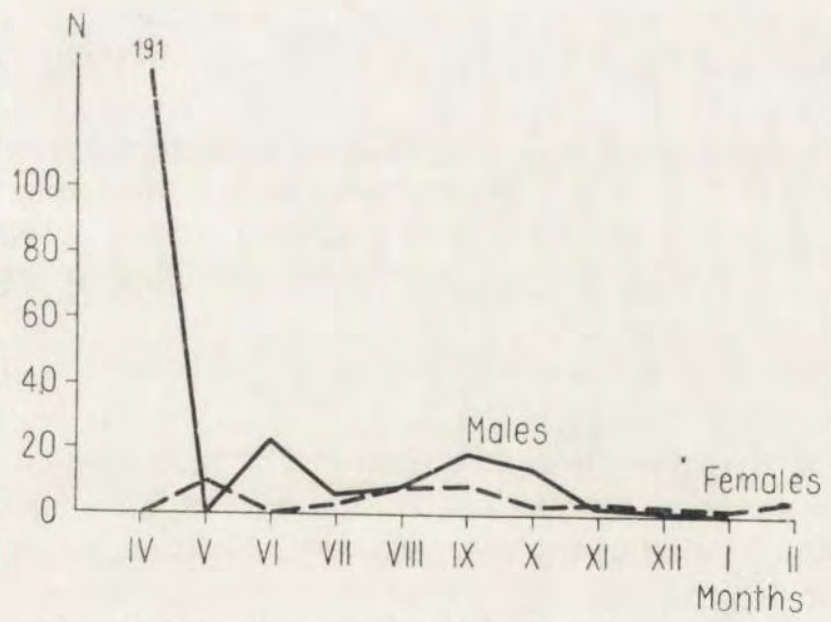

Fig. 11. Intensiveness of infestation of young hares.

distinguished: $A$ (April-July), $B$ (August-November), $C$ (DecemberFebruary), which coincide in time with the character of the extensiveness of infestation.

The index of intensiveness of infection calculated for the whole study period for males was 42.85 . The value of this index for old females was 
33.77. Calculations made by means of the Student test did not confirm the significance of the difference.

The maximum index of intensiveness of infection in old males was noted in May (88.11), and the minimum in January (5.67). Corresponding figures for females were 86.44 in April and 2.33 in November. The most distinct differences between the infestation of males and females was noted during period $A$. It must be emphasised that the character itself of the reduction in the value of this index during period $A$ is slightly different in females than in males. The highest value of the index of intensiveness of infection in females occurs a month earlier, in April, and not in May as is the case with males. This index reaches its minimum also a month earlier in the case of females i.e. in July, and not in August as is the case with males, and therefore period $A$ in the intensiveness of infestation of males in fact ends not in July but in August.

In period $B$ the maximum values of the index for females occur in August, and for males in September. In period $C$ the corresponding values of the index for males are connected with December, and for females with January.

Differences in intensiveness of infection according to sex in each period (treated as different samples) are as follows: period $A-13.55$, in favour of males, period $B-6.25$ in favour of females. In period $C$ the difference is very small (0.38) in favour of the males. The Student test does not, however, confirm that the differences in infestation of the sexes are significant.

The whole study period was characterised by a decrease in the mean number of mites on one hare, and decrease in the differences in intensiveness of infestation of the sexes. The tendency to even out differences in intensiveness of infestation between the sexes appears together with a decrease in the extensiveness of infestation.

The material was not abundant enough to permit of analysing the intensiveness of infection of young hares (Fig. 11), nevertheless the data on differences in intensiveness of infestation of youg hares in comparison with old hares are very interesting. The total (calculated for the whole of the study period) index of intensiveness of infestation of young female hares is far lower than that in the case of adult hares, being 5.32, as compared with 32.77 for old hares. Intensiveness of infection of young male hares is similar, giving a figure (after excluding data from April collected from one hare only -191 mites) 13.83 , whereas the figure for old males is 42.85 .

\section{DISCUSSION OF RESULTS}

I did not find any study of the age structure of parasite mites in the jiterature at my disposal (apart from the paper by Polimpsestov, 
cited after D u bi n in, 1950). Polimpsestov demonstrated that one of the causes of the fluctuation in numbers of mites of the genus Psoroptes expressed in numerically considerably changes of "vegetative" winter populations to "generative" numerically small populations passing into diapause in the summer - are phenomena connected with the host's moulting process.

This process has a fundamental effect on the variation in moisture of the fur and the layer of air nearest the skin. Not only the numbers and age structure of the population but also the rate of development of the mites depend on variations in the moisture of the air layer next the skin and the moisture of the sheep's fleece.

Towards the $\in$ nd of the autumn the regenerative processes in the skin are completed and a period of physiological atrophy ensues, as a result of which the moisture of both fleece and the air layer next the skin increases. Under such conditions the teleonymphs which passed through the diapause in the summer pass into the final process of moulting, then after transition to the class of mature females lay their eggs. The whole cycle of development from egg to sexually mature individual lasts on an average from 14-20 days. During this period not only are the most densely infested individuals encountered, but the infection is constant and maintained up to the spring. In the spring the epidermis and the true skin of the host thickens, the activity of its sweat glands increases and the fur starts to moult. This involves a decrease in the moisture of the fur and air layer next the skin. In the spring and summer a large number of animals free themselves of parasites. In March and April, as a result of the change in the existence conditions of the mites, diapausing nymphs appear. These nymphs pass through the moulting process and are not capable of eggs laying until the autumn. At the end of June the sheep which were previously infested are free of mites, only single individuals remaining in their fleece.

It is clear from the above material that Polimpsestov distingvishes two groups of population: the autumn-winter one, that is, "vegetative", and the "generative" one, passing into diapause in the summer. The "vegetative" winter population is characterised by high reproduction rate and acceleration of the development cycle of mites, the summer "generative" diapausing population by its lack of development and low numbers. This state is directly dependent on habitat conditions (fleece, skin), and the rhythm of changes is in agreement with the complex of phenomena accompanying the moulting process, or the completion of this process.

Using Polimpsestov's terminology, it is possible to distinguish two categories of population in the present material: "vegetative", repro- 
ducing rapidly and "generative", diapausing. The "vegetative" population from period $B$ (July-November), while the "generative" population in diapause is formed by groups from period $A$ (April-June) and period $C$ (December-February). These phenomena are illustrated by Fig. 6 and Table 7 .

What facts argue in favour of the populations from periods $A$ and $C$ being considered as "generative", diapausing populations? In periods $A$ and $C$ that part of the population termed "juvenile" forms the dominating group. The period of absolute predominance of this group lasts from April to June, then from December to February. The character of the curve indicates that the predominating number of nymphs do not pass during these periods to the class of females or males, but remain in a state of diapause. The group of individuals forming that part of the population termed the group of sexually mature individuals decreases in numbers in period $A$, and in period $C$ after the drop in December and January increases slightly. The decrease in the numbers of this group of mites can surely be explained only by mortality among adult individuals. It must be concluded that not the whole population (all stages of development) are in diapause, but only the nymphs and probably the teleonymphs.

What data can be given in support of this view? It was found that the participation of pregnant females was small throughout the whole study period. The percentage of larvae is also slight. The percentage of eggless females is higher. Nymphs and males form the groups with the highest percentage of participation (Tab. 7). Therefore fluctuations in the percentages of these groups has a fundamental effect on the domination of either the juvenile or the sexually mature population. In period B (July-November) variations are both violent and very rapid. During period $A$ (April-June) and period $C$ (December-February) there are no sudden fluctuations, and all changes tend in one direction. The pregnant females and larvae recorded throughout the whole study period and the level of their numbers were constantly low. This state can only provide evidence that the development rate of eggs and larvae is very rapid and differs only slightly in the three periods distinguished in the life of the population. Considerable fluctuations in the percentage of nymphs during perfod $B$ and one-direction variations in periods $A$ and $C$ form evidence of the change in the rate of transition by the nymphs to the group in the population formed by sexually mature individuais. In the late summer and autumn (period $B$ ) this rate is very rapid, and in the winter and spring (periods $A$ and $C$ ) - slower. In periods $A$ and $C$ the time during which the majority of the nymphs passes to the group of sexually mature individuals is at least 3 months. During period $B$ this time comes within the limits of one month. Such great differences in the development rate 
of nymphs justify the statement that it is the nymphs (probably teleonymphs) which form the diapausing stage of development in a population of L. gibbus.

The data given above justify the identification of the populations of $L$. gibbus in periods $A$ and $C$ as "generative" populations, in diapause and therefore they differ from the case with the genus Psoroptes. These same proofs make it possible to define the populations with a rapid development rate, such as that of the population in period $B$, as a "vegetative" non-diapausing population.

The fact is generally well-known in parasitology that extensiveness and intensiveness of infestation are seasonal in character. This phenomenon was thoroughly investigated in the case of lice ( $\mathrm{H}$ a r ke m a, 1936; $\mathrm{D} \mathrm{u} \mathrm{b}$ in in, 1950). The greatest numbers of these parasites and the highcst number of infested hosts are connected with the winter period. Infestation of sheep by mites of the genus Psoroptes is similar in character (D ub i n i n, 1950). According to this author the degree of infestation is caused by a change in the living conditions of the ectoparasites (e.g. mites of the genus Psoroptes). The mechanism regulating the numbers of ectoparasites is very simple. Under favourable conditions the mites more rapidly attain sexual maturity, their numbers increase and attain a maximum (e.g. a "vegetative" population of mites of the genus Psoroptes). Under unfavourable conditions the mites die, the remaining individuals enter diapause, and their numbers reach a minimum (e.g. a "generative" population of mites).

Extensiveness and intensiveness of infection of hares by L. gibbus are also seasonal in character. The existence of populations with features characterising "vegetative" and "generative" populations was also established, but the mechanism regulating the numbers of these mites differs from that described by Poli mpsestov (D u bi n i $n, 1950$ ).

The difference consists in the fact that the "generative" population in diapause is the population distinguished by the highest index of extensiveness and and intensiveness of infestation (population from period $A-$ fig. 6,8 and 10). This high level of numbers is caused by the diapause of the population, retardation of the individual rate of development of the mites and prolongation of the life-span of individuals entering the population.

The "vegetative" population, not in diapause, of L. gibbus (period Bfig. 6,8 and 10) is characterised by accelerated development rate of individuals and decreased numbers of ectoparasites. During period $B$ the development rate of the mites is three times greater than that in period $A$ and $C$, and extensiveness and intensiveness of infestation during the same period, in comparison with period $A$, decreases. This, apparently strange, 
phenomenon is justified by this accelerated development rate, which is accompanied by shortening of the life-span of each mite. This is borne out by variations each month in the age structure (Fig. 6).

Certain authors regard the level of intensiveness and extensiveness of invasion as dependent on the density of the host population. Mohr \&. L o r d (1960) state that a dense population of rabbits the intensiveness of infestation is high, and where numbers of rabbits are small, infestation is low. M o h r (1961) is of the opinion that an increased amount of contact between individuals in the host population plays an important part in infestation processes. He finds that rabbits which are in closer and more frequent contact with each other are more intensively infested.

Layne (1963) draws attention to yet another factor exerting an important influence on intensiveness of infestation. The author divides all the parasites into two groups - specific and non-specific parasites. He includes in the first group those parasites, the life cycle of which is connected exclusively with one host. The flea Polygenus floridanus Johnson \& Layne is a specific parasite of the mouse Peromyscus floridanus ( $\mathrm{Chapman}$ ). The flea lives on the blood of Peromyscus floridanus, and its development takes place in the mouse's nest, therefore the numbers of the flea population are directly dependent on the number of the hosts. The author succeeded in finding a positive correlation between the abundance of the host and the abundance of the parasite, but it proved impossible for him to find such a correlation for non-specific parasites, the life cycle of which does not depend on one host, e.g. ticks.

It must therefore be expected that if this view is correct, then when discovering other factors affecting the abundance of $L$. gibbus it will be possible to estimate, on the basis of the character of variations in the numbers of the mites, certain of the manifestations of the life of hare populations.

Acknowledgements: I should like to express my grateful thanks to Professor K. Petrusewicz for enabling me to make this study and for creating the conditions which permitted me to do it, to Professor $\mathrm{K}$. Tarwid for his most helpful consultations when working on the material and to $\mathrm{Dr}$. R. A ndr zeje w$\mathrm{sk}$ i for his valuable advice and guidance concerning the investigation methods.

\section{REFERENCES}

1. B e e r, J. R., Cook, E. F. \& S chwa b, R. G., 1960: The ectoparasites of some mammals from the Chiricahua Mountains, Arizona. J. Parasit., 45: 605-613.

2. B u ja lska, G., 1964: Studies on the European hare. IV. Variations in the pelvis and sacrum. Acła theriol., 9, 18: 287-304. Bialowieża.

3. C a boń-R a czy ńska, K., 1964: Studies on the European hare. III. Morphological variation of the skull. Acta theriol., 9, 17: 249-285. Białowieża.

4. D u b in in, V. B., 1950: Kolebanija čislennosti postojannych parazitov mlekopitajuščich. Zurn, obšč, biol., 11: 91-103. 
5. D u b i n i n, V. E., 1955: Nadsemejstvo Listrophoroidea - Klešči gryzunov fauny SSSR, : 124-131. Izd. AN SSSR.

6. Harkema, R., 1936: The parasites of some North Carolina rodents. Eccol. Monogr., 6: 153-232.

7. Mohr, C. O. \& Lord, R. D., 1960: Relation of ectoparasite populations in Northern Illinois. J. Wildl. Mgmt., 24: 290-29i.

8. Moh r, C. O., 1961: The relation of rabbit tick populations to spacing in host populations. .T. Parasit., 47: 605-607.

9. L a yn e, J. N., 1963: A study of the parasites of the Florida mouse. Peromyscus floridanus, in relation to host and environmental factors. Tulane Stud. Zool., 11: $1-27$.

10. Pagenstecher, H., 1862: Listrophorus gibbus, nebst nachtraglichen Bemerkungen über Listrophorus leuckarti. Ztschr. Wiss. Zool,, 11: 156-161.

11. Willmann, C., 1952: Parasitische Milben an Kleinsaugern. Ztschr. Parasit., 15: $392-428$.

12. Zapleta 1, M., 1960: Kratke sdeleni o roztocich nadceledi Listrophoroidea. Zool. Listy, 1: 56-58.

13. Z a vadil, R., 1962: Listroforoza u nasich zajicu. Sb. C.S.A.V. Veterin. med, 7: $167-172$.

Antoni WASYLIK

EADANIA NAD ZAJĄCEM SZARAKIEM. VIII. DYNAMIKA WYSTĘPOWANIA LISTROPHORUS GIBBUS P A G E N S T E C H E R, 1862

Streszczenie

Badania prowadzone w woj. poznańskim od kwietnia 1959 do lutego 1960 r. Obiektem badań było roztocz Listrophorus gibbus Pagens te cher, 1862 występujący na Lepus europaeus, Pallas 1778. Przebadano łącznie 350 martwych zajęcy (Tab. 5) i zebrano 6928 roztoczy (Tab. 6). Badania prowadzono za pomocą 2 metod: metody „wyczesywania” i metody zwanej roboczo metodą „worka”. Podjęto próbę oceny skuteczności stosowanych metod.

Ustalono, że przebieg i skuteczność wyczesywania charakteryzuje się określonymi właściwościami. Przebieg wyczesywania posiada charakterystyczną krzywą, a skuteczność wyczesywania zmienia swoją wartość (Ryc. 1, 2, 3, 4 i Tab. 1, 2, 3, 4). Praktycznie nie jest możliwym wyczesanie wszystkich roztoczy znajdujących się w sierści zająca. Metoda ta musi więc być zaliczona do metod pozwalających szacować tylko wzglęđiną liczebność pasożytów.

Przy metodzie „worka” przeanalizowano znaczenie czasu, który upływa od momentu odstrzelenja zająca do momentu odłowu pasożytów. Ustalono, że zające nie mogą leżeć w worku diużej niż 48 godzin od momentu ich odstrzelenia. Stwierdzono również, że nie wszystkie roztocze opuszczają martwego zająca, część ich pozostaje w sierści, a więc i ta metoda nadaje się tylko do szacowania liczebności względnej.

Nie znaleziono korelacji między metodą ,worka" a metodą „wyczesywania”. Z tego też powodu materiał zebrany za pomocą obydwu metod został poiączony i w rozważaniach traktowany łącznie. Należy spodziewać się, że zsumowanie wyników 2 metod obciążonych błędem selektywności umożliwia zmniejszenie tego błędu, czyli uzyskanie bardziej obiektywnych wyników. 
Ocena skuteczności stosowanych metod wymaga jeszcze bardziej szczegółowego dopracowania. Dlatego też możliwości wnioskowania są ograniczone i pozwalają jedynie na ogólne śledzenie procesów zachodzących w życiu populacji roztoczy, bez m.ożliwości dokładniejszej oceny ich ilościowego nasilenia. Tym nie mniej, stosowane metody, przy zachowaniu odpowiednich warunków, zapewniają powtarzalnośc doświadczeń i ich porównywanie.

Badano zagadnienie ruchliwości roztoczy wyrażające się opuszczaniem martwego zająca przez L. gibbus. Stwierdzono, że w okresie badań (11 miesięcy) zachowanie reztoczy zmieniało się jakościowo. Na tej podstawie wyróżniono 3 okresy aktywności roztoczy. Okres $A$ obejmuje miesiące kwiecień-lipiec, okres $B$ przypada na miesiące sierpień-listopad i okres $C$ trwa przez grudzień-luty. Stwierdzono, że w okresie $B$ ilość roztoczy opuszczających martwe zające w ciągu pierwszej doby od ich odstrzelenia jest większa (w stosunku do wyczesanych) niż w okresach $A$ i $C$. Jakie są przyczyny tego zjawiska i jakı sens biologiczny ono posiada, nie wiadomo.

Badano ksztaltowanie się struktury wiekowej i płciowej L. gibbus. Stwierdzono występowanie wszystkich wyróżnionych stadiów rozwojowych roztoczy (larwy, nimfy, samce i samice) oprócz jaj. Proporcje między poszczególnymi sładiami rozwojowymi nie są stałe, a ulegają wahaniom. W okresach $A$ (kwiecień-czerwiec) i $C$ (grudzień-luty) dominują osobniki zwane juwenilnymi. Okres B (lipiec-listopad) charakteryzuje się gwałtownymi zmianami struktury wiekowej. W jednym miesiącu dominują osobniki należące do części populacji zwanej juwenilną, a w następnym esobniki zaliczane do populacji dojrzalej plciowo (Ryc. 6, Tab. 7). Wahania struktury wiekowej populacji roztoczy jeśli i zależą od czynników abiotycznych (np. temperatury, wilgotności) to nie w sposỏb bezpośredni a pośrednio.

Na zającach mlodych $L$. gibbus również stwierdzono występowanie wszystkich wyróżnionych stadiów rozwojowych roztoczy. W miesiącach, w których stwierdzono występowanie samic ciężarnych i larw, ich udzial procentowy w populacji roztoczy na zającach młodych był wyższy niż w populacjach roztoczy na zającach starych (Tab. 7 i Tab, 8). Stwierdzono, że nimfy odgrywają najważniejszą rolę przy zasiedlaniu zajęcy wolnych dotychczas od roztoczy. Swiadczy o tym fakt, że obecność ich notowano w ciągu calego okresu badań (inne stadia rozwojowe byly notowane tylko od 6-9 miesięcy). Udział procentowy nimf był również najwyższy.

Ekstensywność i intensywność zapasożycenia ma charakter sezonowy (Ryc. 8, Rjc. 10). Najwyższy wskaźnik ekstensywności i intensywności zapasożycenia zajęcy zanotowano w okresie $A$ (kwiecień-lipiec), średni w okresie $B$ (sierpień-listopad) i najniższy w okresie $C$ (grudzień-luty). Intensywność zapasożycenia zajęcy młodych jest wyraźnie niższa od intensywności zapasożycenia zajęcy starych.

Mechanizm regulujący liczebność populacji $L$. gibbus jest związany ze strukturą wiekową i plciową ektopasożytów, chociaż jest inny niż u roztoczy z rođzaju $P$ soroptes. 